\title{
Submerged Groundwater Discharges as Source of Fecal Material in Protected Karstic Coastal Areas
}

\author{
Cristian Kantun Manzano, ${ }^{1}$ Flor Arcega-Cabrera ${ }^{(D)},{ }^{1,2}$ Morgane Derrien $\left(\mathbb{D},^{3}\right.$ \\ Elsa Noreña-Barroso, ${ }^{2}$ and Jorge Herrera-Silveira ${ }^{1}$ \\ ${ }^{1}$ Centro de Investigación y de Estudios Avanzado del IPN-Mérida, Km 6, Antigua Carretera a Progreso, Cordemex, \\ Mérida, YUC, Mexico \\ ${ }^{2}$ Unidad de Química en Sisal, Facultad de Química, Universidad Nacional Autónoma de Mexico, Puerto de Abrigo, \\ S/N, 97356 Sisal, YUC, Mexico \\ ${ }^{3}$ Department of Environment and Energy, Sejong University, Seoul 143-747, Republic of Korea
}

Correspondence should be addressed to Flor Arcega-Cabrera; farcega@unam.mx

Received 29 September 2017; Revised 28 December 2017; Accepted 4 February 2018; Published 5 March 2018

Academic Editor: Maurizio Polemio

Copyright (c) 2018 Cristian Kantun Manzano et al. This is an open access article distributed under the Creative Commons Attribution License, which permits unrestricted use, distribution, and reproduction in any medium, provided the original work is properly cited.

\begin{abstract}
Coastal zones are vital for their ecosystem services and socioeconomic value. Accordingly, several zones have been protected to limit anthropogenic development and to avoid environmental degradation. Nevertheless, some of these protected areas keep deteriorating probably related with anthropogenic contributions not considered in legislation. Specifically, submerged groundwater discharges (springs) could be releasing anthropogenic materials carried from remote inland areas to the coast. Here we evaluate the role and temporal variation of submerged groundwater discharges as sources of anthropogenic materials using the $5 \beta$-stanol $\mathrm{C}_{27}$ markers in the natural protected area of Dzilam de Bravo, Yucatán, Mexico. Results demonstrate that (1) submerged groundwater discharge flux velocity and direction vary between hydrological season, exhibiting higher flow rates in Nortes season contrary to dry season and (2) the presence of coprostanol and epicoprostanol (anthropogenic fecal matter markers) in sediments surrounding the submerged groundwater discharges provides proof of allochthonous anthropogenic fecal material in a protected area, probably from remote inland sites. Thus, it is vitally important that inland anthropogenic materials transported in groundwater and released in the coastal environment by submerged groundwater discharges be considered in protection plans, like protection perimeters, for coastal zones.
\end{abstract}

\section{Introduction}

Continental water in the Yucatán Peninsula (YP) is entirely subterranean because it is a carbonated karstic aquifer. Importantly, groundwater flows preferentially from south to north through pores, fissures, and fractures. One of the main families of fractures is located into the ring of cenotes (sinkholes), where the groundwater flows preferentially, but not uniquely, from the center of the peninsula towards the northeast and northwest coasts [1]. In the northwest coast, specifically in Dzilam de Bravo (DB), submerged springs are widely distributed throughout the zone $[2,3]$. These springs formed by karstification allow the mix of groundwater and seawater, producing estuarine conditions in a coastal marine area. Submerged groundwater discharges (SGD) could be punctual through an opening in the marine soil or diffuse trough the sediments [4].

Springs with significant volumes of water could be indicating a more hierarchical aquifer with large karstic conduits for this area. Within these springs, high concentrations of dissolved inorganic nutrients have been reported [5]. Therefore, it has been hypothesized that these springs may also be releasing anthropogenic materials from inland activities into the coastal environment [6-8].

According to Polemio and Limoni [9], quality and quantity of SGD produce different effects: (a) increase or decrease the seawater intrusion withdraws (seaward) or advances (inland), respectively; (b) affect the chemical characteristics 
of coastal surface waters with complex ecological effects; (c) groundwater can transport pollutants and nutrients modifying the budget of carbon, nitrogen, and phosphorus, causing eutrophication and algal blooms or affecting benthic habitats.

Sterols and stanols are classically used as molecular markers to characterize the sources of natural organic matter (e.g., marine and terrigenous) $[10,11]$ and to identify anthropogenic inputs (e.g., fecal material related to human activities) [12-14]. Due to their ubiquity and diagenetic and chemical stability, these compounds have been widely used as tracers for the sources, transport, and transformation of biogenetic material $[15,16]$ in coastal zones $[11,17,18]$. Specifically, sterols and stanols have also been used in karstic coasts to show submarine groundwater discharges inputs in a sensible ecosystem $[6-8,13-17,19,20]$.

Cholesterol is the predominate sterol produced by invertebrates and marine zooplankton, whereas phytoplankton and algae can synthesize a wide array of sterols, including large amounts of phytosterols $[10,21,22]$. The most common phytosterols are campesterol, stigmasterol, and $\beta$-sitosterol, which come from decomposed vegetation [10,23], as well as dinosterol, which is specifically produced by dinoflagellates [24]. Contributions from anthropogenic fecal sources can be characterized via the occurrence of the $5 \beta$-stanol $\mathrm{C}_{27}$ (e.g., coprostanol and epicoprostanol) compounds [11-14, 25] that are byproducts of intestinal anaerobic microbial reduction of cholesterol in higher animals [12].

This study focuses on identifying spatial and temporal variations on the distribution of sterols and stanols in the zone of springs in Dzilam de Bravo, specifically around the spring known locally as the X'Buya-Ha ("the whirlpool"). This spring is the largest and most important source of groundwater to the coastal zone [26]. The analysis of sterols and stanols in this zone was used to show the probable role of springs in the release of allochthonous organic and fecal material into protected coastal zones with low development degree.

\section{Materials and Methods}

2.1. Study Area. The port of Dzilam de Bravo is located between $21^{\circ} 19^{\prime}$ and $21^{\circ} 32^{\prime}$ north latitude and $88^{\circ} 35^{\prime}$ and $88^{\circ} 58^{\prime}$ west longitude. The climate is semiarid and hot $\left(\mathrm{BS1}\left(\mathrm{h}^{\prime}\right)\right.$ INEGI climate code-44). Seasonal climatic variations are marked by three periods: rainy season from June to October, the "Nortes" season (a period of cold fronts marked by strong winds from the north) from November to February, and the dry season from February to May.

Enriquez et al. [27] reported that, in Nortes season in the Yucatán Shelf, subtidal variability of circulation is dominantly forced by local surface momentum fluxes (wind stress), increasing turbidity due to fine sediments resuspension. Therefore, each Nortes season surface sedimentary column could be redefined depending on the wind intensity.

The zone influenced by coast springs is located $6 \mathrm{~km}$ to the east of the port of Dzilam de Bravo. This area contains $\mathrm{X}$ 'Buya-Ha, the largest submerged spring in the region. Water discharge flow rates from this spring may be as high as $2 \mathrm{~m}^{3} \mathrm{~s}^{-1}$ during the rainy season. Studies have demonstrated that this particular spring is responsible for the largest contribution of groundwater and nutrients along the coast [26].

Regarding groundwater regional flux, the hydrological conceptual model of this system states that the main regional flow goes from the southern to the northern part of the state [6], although in the ring of cenotes, which is a semicircular accumulation of sinkholes, water transport preferentially goes from the center of the state to the eastern and western coastal areas $[1,28]$. Hydraulic gradient of the aquifer has been reported to be $7 \mathrm{~mm} \mathrm{Km}^{-1}$; therefore for inland groundwater to reach the coastal area it could take from weeks to months [29]. Then, to detect SGD promoted environmental changes in the coast, it would be recommendable to monitor them weeks or months after the rainy season.

Legislation protects Dzilam de Bravo since it is located at the North Coast State Swamp and Mangrove Reserve of the state of Yucatán. Therefore, in theory, the reserve is protected from in-site anthropogenic wastewater and protection perimeters [30] are established, but inflows of polluted groundwater to the coastal area are not considered. Then, the highly complex nature of the region's hydrogeological system and the susceptibility of groundwater to contamination due to the karstic rock need to be explored and studied for a better diagnosis of the situation.

2.2. Sampling Design. Sampling campaigns were carried out in two seasons: Nortes season (Feb 2012) and the dry season (May 2013). For each campaign, 12 samples of surface sediments (upper $5 \mathrm{~cm}$ of the sedimentary column) were collected. The sampling consisted of four transects organized in a cross, with the center located on the X'Buya-Ha spring (Figure 1). Each transect measured $5 \mathrm{~m}$ in length and sediments were collected at $1 \mathrm{~m}, 3 \mathrm{~m}$, and $5 \mathrm{~m}$ along it ( 3 samples per transect). Immediately after collection, the sediment samples were stored at $4^{\circ} \mathrm{C}$ in a closed icebox and transported to the laboratory for analysis. Then, sediments were freeze-dried for 3 days and finally sieved to obtain the $<0.500 \mathrm{~mm}$ fraction (fine grain (FG)) that was used for extraction and steroid analysis.

2.3. X'Buya-Ha Spring Velocity and Flow Rate. The spring's discharge flow velocity rates $\left(\mathrm{m}^{3} \mathrm{~s}^{-1}\right)$ were measured in Nortes and dry seasons, using a Nortek Vector Velocimeter. The three components of velocity $(X, Y$, and $Z)$ were measured at specific points $(15 \mathrm{~cm}$ from the transect). The equipment was programed to make continuous measurements at $1 \mathrm{~Hz}$ for a period of 24 hours from 12 December 2012 to 22 May 2013. The nominal interval of velocity was fixed at $4 \mathrm{~m} \mathrm{~s}^{-1}$ to ensure that velocity measurements did not surpass this maximum value. Since spring flux behavior is multidirectional, flux analysis was performed using a 3-coordinate function plus time $[4] V=V(x, y, z)$ with the following formula:

$$
V=\sqrt{x^{2}+y^{2}+z^{2}} .
$$

The resultant magnitude was related to the spring diameter to obtain the flux $\left(\mathrm{m} \mathrm{s}^{-1}\right)\left(\mathrm{m}^{2}\right)=\mathrm{m}^{3} \mathrm{~s}^{-1}[26]$. 


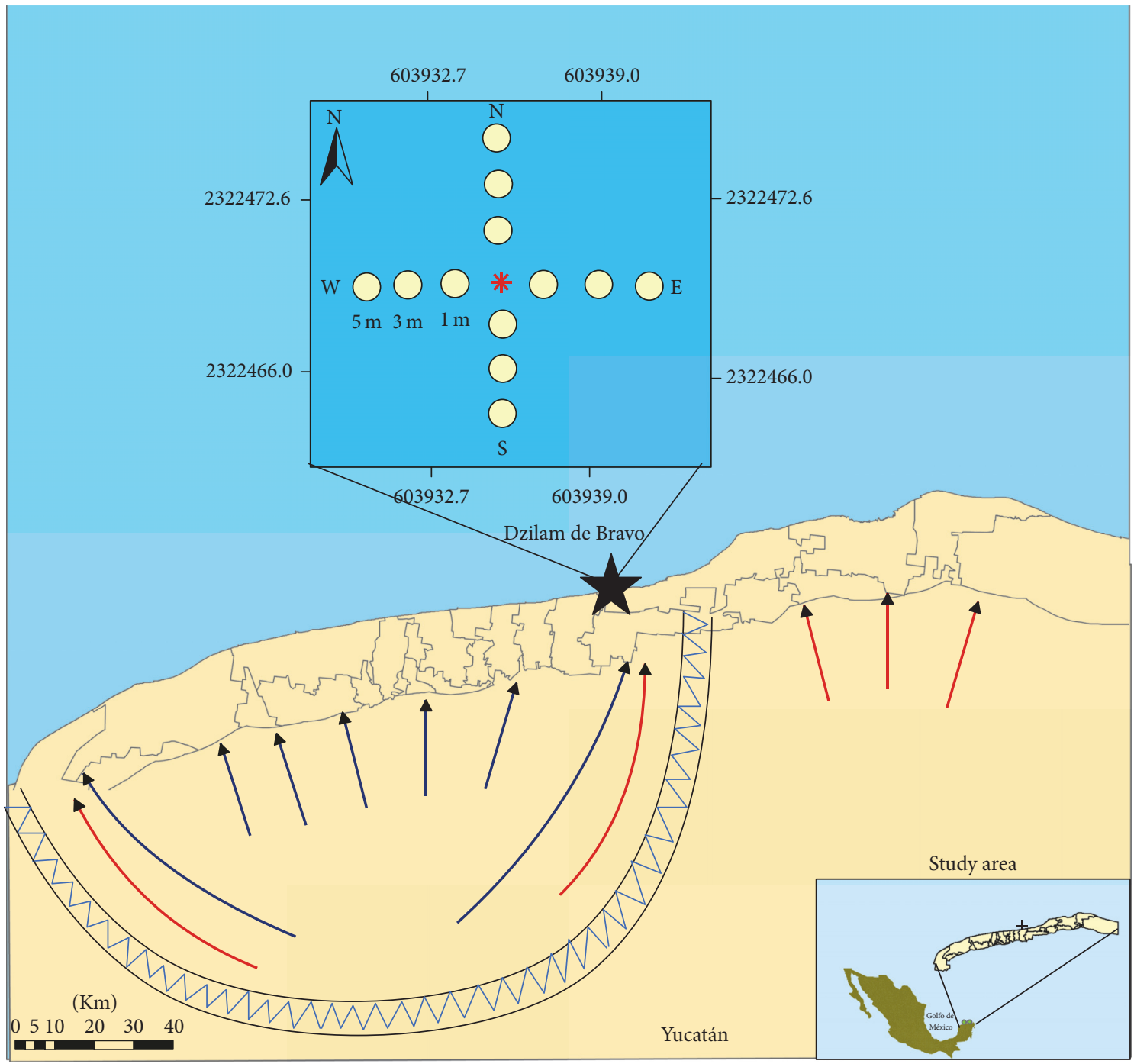

* X’Buya-Ha

FIGURE 1: Study area showing regional fluxes (arrows) and spatial sampling sites distribution in the submerged groundwater discharge. Black star represents Dzilam de Bravo reserve; red asterisk represents X’Buya-Ha spring; blue zigzag line represents ring of cenotes.

2.4. Total Carbon, Total Nitrogen, Total Phosphate, Organic Matter, and Carbonates in Sediments. Total carbon (TC) and total nitrogen (TN) were determined via gas chromatography, using an elemental autoanalyzer (Flash EA-1112 series model). Total phosphorous (TP) analysis was performed via the following method. First, the sample was prepared by calcination at $550^{\circ} \mathrm{C}$, followed by agitation with $\mathrm{HCl} \mathrm{mol} \mathrm{L}^{-1}$, and finally filtered. Then, TP was determined using spectrophotometric adsorption at an optical wavelength of $885 \mathrm{~nm}$ [31]. Organic matter $(\mathrm{OM})$ was analyzed via calcination and measurement of weight loss at 550 and $950^{\circ} \mathrm{C}$ [32]. Carbonates were determined by $\mathrm{CO}_{2}$ generation following Loring and Rantala [33].

2.5. Sterols and Stanols Analysis. Extraction and fractionation were performed following the methods previously described [7, 16]. Extraction was performed using a ColePalmer Ultrasonic Processor, 500 and $750 \mathrm{~W}$, Model CV.
Briefly, $2 \mathrm{~g}$ of freeze-dried sediment (e.g., spiked with deuterated cholesterol (cholesterol-2,2,3,4,4,6- $\mathrm{d}_{6}$ ) standard in DCM (dichloromethane, Sigma-Aldrich, 99.8\%) (2 $\mu \mathrm{g}$ ) as recovery standard) was placed in a $40 \mathrm{~mL}$ glass tube and ultrasonically extracted consecutively with $30 \mathrm{~mL}$ of methanol (SigmaAldrich, 99.9\%), a mix MeOH/DCM (1:1, v:v), and DCM. Extractions were performed with $40 \%$ of the sonicator amplitude during $7 \mathrm{~min}$, with $1 \mathrm{~min}$ switch-on and $2 \mathrm{~min}$ switch-off for each solvent. Then, the suspension was filtered through a glass filter (Whatman GF/C, $1.2 \mu \mathrm{m}$ ) and then concentrated using a rotary evaporator (i.e., $60^{\circ} \mathrm{C}$, $337 \mathrm{mbar}$ ). The combined extract was redissolved in a fixed volume of hexane before the fractionation into three fractions (aliphatic, aromatic, and polar) on silica column. The polar fractions of each sample, containing the sterol and stanol compounds, were finally concentrated using a gentle flux of $\mathrm{N}_{2}$ gas. 
Internal standard (5 $\beta$-cholestane, Sigma-Aldrich) was added to the samples and then the sample was derivatized with N,O-Bis(trimethylsilyl) trifluoroacetamide with trimethylchlorosilane (Sigma-Aldrich, 99\% BSTFA $+1 \%$ TMCS). Derivatization was performed at $70^{\circ} \mathrm{C}$ for $30 \mathrm{~min}-$ utes. Sterols and stanols were measured using a gas chromatograph coupled with a mass spectrophotometer (Agilent MSD 5975B VL with Series 7683B automatic injector). Injection was carried out in split-less mode at $290^{\circ} \mathrm{C}$. A Zebron ZB5MSi silica capillary column (Phenomenex; $30 \mathrm{~m}, 0.25 \mathrm{~mm}$ i.d., film thickness: $0.25 \mu \mathrm{m}$ ) was used for the separation with the following temperature program: initial temperature was set at $150^{\circ} \mathrm{C}$ for one minute before increasing at a rate of $20^{\circ} \mathrm{C} \mathrm{min}^{-1}$ to $250^{\circ} \mathrm{C}$ and then to $300^{\circ} \mathrm{C}$ (held $14 \mathrm{~min}$ ) at $2.5^{\circ} \mathrm{C} \mathrm{min}^{-1}$. Helium flow (UAP) was fixed at $0.8 \mathrm{~mL} \mathrm{~min}^{-1}$. Data acquisition was performed in SIM (selective ion monitoring). Quantification was based on the internal standard method. The quantification method utilized five-point calibration curves $\left(0.1,0.5,1,5\right.$, and $\left.10 \mu \mathrm{g} \mathrm{mL}^{-1}\right)$ with a constant internal standard concentration of $4 \mu \mathrm{g} \mathrm{mL}^{-1}$. All the calibration curves for each sterol showed high linearity $\left(r^{2} \geq 0.995\right)$. Limit of detection (LD) of each compound was estimated by calculating the signal-to-noise ratio $(\mathrm{S} / \mathrm{N})$ for three solutions containing the target compounds at 5, 10, and $15 \mu \mathrm{g} \mathrm{mL}^{-1}$. Each solution was analyzed 10 times. LD was defined as the concentration for which $\mathrm{S} / \mathrm{N}$ was $>3$.

2.6. Multivariate Analysis. Multivariate analysis, using StatSoft's STATISTICA, was conducted in order to identify the variables that play a significant role in the presence and mobility of sterols and stanols in this study. Principal Component Analysis (PCA) and Factor Analysis (FA) [7, 13] were performed using the nutrients, sterols, and stanols concentrations, fine grain, and organic matter content data. All data were normalized before multivariate analysis $[7,8]$.

\section{Results and Discussion}

3.1. Direction, Velocity, and Flow Rate: X'Buya-Ha Spring. The in situ measurement of X'Buya-Ha's flow rate for both seasons can be observed in Table 1.

For Nortes season (Figure 2), it is indicated that the most intense flows show north and west directions. $Z$ component showed less intensity in the upward direction. The flow generated by these intensities can be summarized by flow rates from 0.59 to $1.63 \mathrm{~m}^{3} \mathrm{~s}^{-1}$. In dry season, flow rates (Figure 3) were lesser than Nortes season. Directionally, the $Y$ component dominates with negative values, which indicates that the flow direction in dry season is towards the west. $X$ component's intensity was low. Also, X'Buya-Ha's flow rate in dry season showed values from 0.24 to $0.78 \mathrm{~m}^{3} \mathrm{~s}^{-1}$.

SGD flux variation highly depends on tide level [34] that could generate depth changes $( \pm 60 \mathrm{~cm})$. The vertical movement produced by the tide changes the flux patterns of the SGD in a tide cycle [35]. Then, in high tide conditions, the marine water column blocks or diminishes SGD.

The measured flow rates in both campaigns are shown in Table 2 and they were comparable with those previously

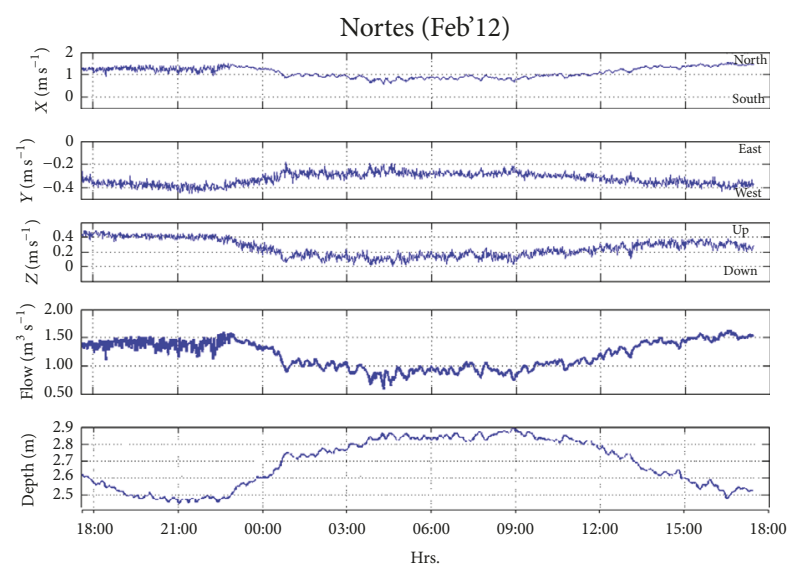

FIGURE 2: Direction, velocity, and flux in X'Buya-Ha spring during the Nortes season (Feb 2012). The $x$-axis shows 24 hours of observation from 18:00 on 2/12/12.
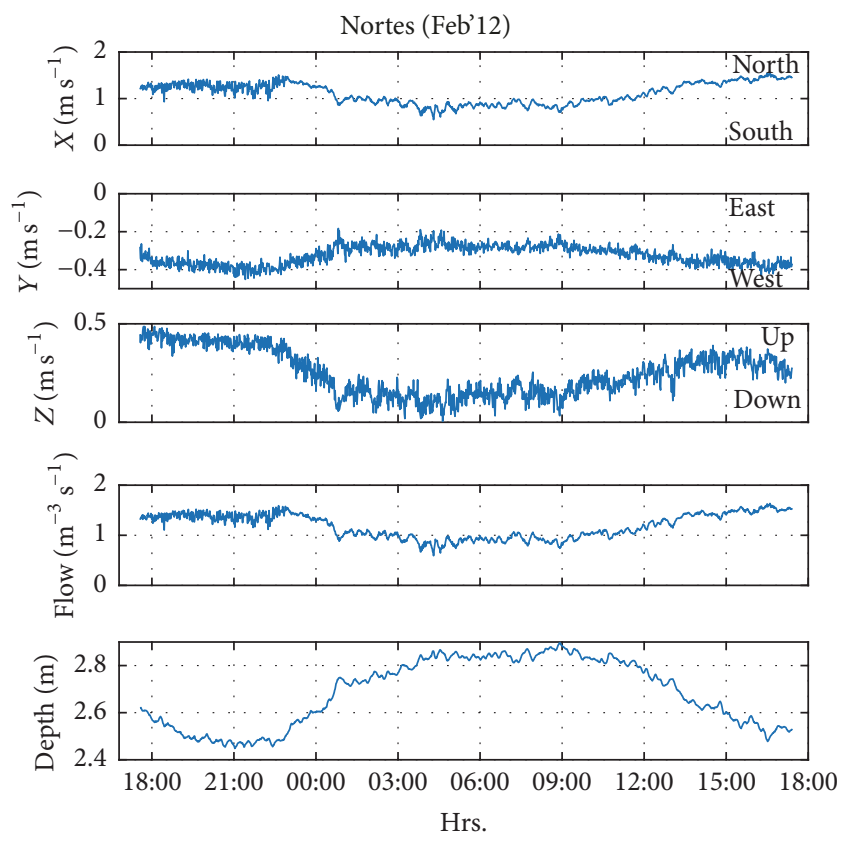

FIgURe 3: Direction, velocity, and flux in X’Buya-Ha spring in dry season (May 2013). The $x$-axis shows 24 hours of observation from $0: 00$ on $3 / 22 / 13$.

described [36]. They are principally determined by variation in precipitation between seasons, with greater intensities in Nortes season than in dry season.

3.2. Nutrients in Sediments. The proportions of total carbon, nitrogen, phosphorous, organic matter, and carbonates (TC, TN, TP, OM, $\mathrm{CO}_{3}{ }^{=}$, respectively) in Nortes season campaign (Table 2). The lowest values were observed for the TP, followed by TN. OM was present in high concentrations and probably as product of the decomposition of vegetal material (mainly marine grasses) that fully covers the area [5]. These grasses were likely torn apart from the adjacent substratum by the strong waves generated by Nortes winds associated with 
TABLE 1: Flow velocity and direction from the X'Buya-Ha discharge. " $X$ " represents flows oriented north-south, " $Y$ " represents flows oriented east-west, and " $Z$ " represents upward flow.

\begin{tabular}{lcccccccc}
\hline & & \multicolumn{3}{c}{ Nortes season } & \multicolumn{3}{c}{ Dry season } \\
& $X\left(\mathrm{~m} \mathrm{~s}^{-1}\right)$ & $Y\left(\mathrm{~m} \mathrm{~s}^{-1}\right)$ & $Z\left(\mathrm{~m} \mathrm{~s}^{-1}\right)$ & Flux $\left(\mathrm{m}^{3} \mathrm{~s}^{-1}\right)$ & $X\left(\mathrm{~m} \mathrm{~s}^{-1}\right)$ & $Y\left(\mathrm{~m} \mathrm{~s}^{-1}\right)$ & $Z\left(\mathrm{~m} \mathrm{~s}^{-1}\right)$ & $\mathrm{Flux}\left(\mathrm{m}^{3} \mathrm{~s}^{-1}\right)$ \\
\hline Min & 0.54 & -0.18 & 0.01 & 592 & 0.00 & -0.06 & 0.04 & 240 \\
Quart 1 & 0.90 & -0.28 & 0.15 & 961 & 0.02 & -0.42 & 0.26 \\
Median & 1.13 & -0.32 & 0.24 & 1209 & 0.03 & -0.63 & 0.34 & 799 \\
Quart 3 & 1.32 & -0.37 & 0.35 & 1413 & 0.04 & -0.65 & 0.35 & 723 \\
Max & 1.54 & -0.45 & 0.49 & 1634 & 0.12 & -0.7 & 0.40 & 780 \\
\hline
\end{tabular}

entering cold fronts [37]. The proportion of $\mathrm{CO}_{3}{ }^{=}$was high as expected from the carbonated soils that predominate in YP's marine zones [38].

The data from dry season showed significant differences $(p<0.05)$ with respect to the Nortes season data. TN was lower in dry season. TC, OM, and TP followed the same pattern during both campaigns. On the other hand, $\mathrm{CO}_{3}=$ increased from $36 \%$ (median in Nortes season) to $54 \%$ (median dry season), as result of a reduction in the input of organic material. This reduction was also reflected in the water emerging from X'Buya-Ha in the dry season [36]. This pattern showed that nutrient contributions were proportional to the velocity of submerged discharge [26]. Therefore, if nutrients input was related to the submerged discharge, then it could be feasible that the same situation exists for sterols and stanols.

\subsection{Sterols and Stanols}

3.3.1. Nortes Season (February 2012). Eleven sterols and stanols were detected and quantified in the sediment samples of the Nortes season (Table 2). Their spatial distribution around X'Buya-Ha was represented in Figure 4.

$\mathrm{CH}$ and SI were present in all of the sampling stations (12 stations). These compounds are commonly associated with the occurrence of marine organic matter [16], although SI also could be related to terrestrial organic matter and more specifically to higher plants $[39,40]$ according to its stereoisomeric configuration.

However, the presence of ST in most of the samples sites (i.e., [11]) and CA and STL can confirm a terrestrial input from higher plants. By contrast, in some station (e.g., [8]), DI was detected. In that case, a marine organic matter input should be preferred as source assignment [16, 24, 39]. CO and EP were present in at least five sampling stations. CO represents about $60 \%$ of the total sterol/stanol content in human feces [12], and it shows the presence of fecal contamination of human origin related to wastewater discharge [25, 41-43]. CO and EP showed concentrations of up to 96.06 and $96.13 \mu \mathrm{g} \mathrm{g}^{-1}$, respectively (Table 2 ). These values are similar to those reported in the Great Lake, Canada, indicating fecal material in a zone [44]. In the present study, the occurrence of these two compounds suggests the input of fecal material from higher mammals in the area surrounding the X'Buya-Ha spring, where no anthropogenic activities take place. Furthermore, as this area is classified as protected karstic area with no anthropogenic activities and thus no punctual sewage inputs, the only potential source of fecal material in this coastal zone might come from submerged groundwater discharges. Therefore, anthropogenic materials would be transported from far inland to the coastal area by groundwater due to the properties of this karstic environment $[5,7]$ and consequently lead to a release of this fecal material to the coastal area through submarine spring X'Buya-Ha.

Factor analysis (Table 3) for Nortes season results in formation of three factors explaining $82 \%$ of the variability in the data. The most contributive variables of factor 1 were STL, TC, TN, OM, and inversely $\mathrm{CO}_{3}{ }^{=}$. The association of STL with nutrients and organic material in sediments could indicate that nutrients in sediments came from vegetal material, although this needs to be investigated further since $\mathrm{CA}$ and ST are not present in this factor [24]. $\mathrm{CO}_{3}{ }^{=}$were inverse in the first factor because they play the role of diluent in the sediments [33]. The high significance of the variable could be result of the high $\mathrm{CO}_{3}=$ abundance in the area $[38,45]$. The significant variables for the second factor were $\mathrm{CH}, \mathrm{CHL}, \mathrm{CA}, \mathrm{SI}$, and SIL. $\mathrm{CH}$ is considered as a marine organic matter marker; CA, SIL, and SI are commonly used as markers of higher plants. The occurrence of $\mathrm{CH}$ and SI can indicate a mix origin of marine and terrestrial organic matter. The main significant variables for factor 3 were $\mathrm{CO}$ and EP, compounds usually associated with anthropogenic fecal matter input $[12,25]$.

Principal Component Analysis (Figures 5(a) and 5(b)) was performed using all data collected in Nortes season. The first two factors of the PCA explained $62 \%$ of the total variance. The plot showed and results in the formation of 3 groups: one of them (circled in red) shows organic and fecal material presence ( $\mathrm{CO}$ and EP are coinciding in the same plot as red circle sites; see Figure 5(a)). This group is integrated by all of the samples taken $5 \mathrm{~m}$ away from the X'Buya-Ha spring; also, two samples collected at $1 \mathrm{~m}$ from the spring and one sample collected $3 \mathrm{~m}$ from the spring belong in this group. This pattern indicates that the preferential deposition of suspended material could primarily occur at $5 \mathrm{~m}$ away from the spring. Nortes season leads to a higher flow of the spring than in dry season; thus suspended materials could more easily transport from a wide distance. However, this pattern could also be explained by variations in the sedimentation process due to flow rate in the spring [46], for example, at low flow rate, as during flood tide particles settle down at a preferred distance of $1 \mathrm{~m}$ [35].

For the other sites, it seems that the fecal matter input is lower than the nutrient input, although there is not enough 
TABle 2: Nortes and dry seasons median, minimum, and maximum $(N=12)$ nutrient content $(\%)$, sterols, and stanols $\left(\mu \mathrm{gg} \mathrm{g}^{-1} \mathrm{D} . \mathrm{W}.\right)$ in sediments surrounding X'Buya-Ha. TC: total carbon; TN: total nitrogen; TP: total phosphorus; OM: organic matter; $\mathrm{CO}_{3}{ }^{\circ}$ : carbonates; $\mathrm{CO}$ : coprostanol; EP: epicoprostanol; CH: cholesterol; CHL: cholestanol; CA: campesterol; CAL: campestanol; ST: stigmasterol; STL: stigmastanol; DI: dinosterol; SI: sitosterol; SIL: sitostanol.

\begin{tabular}{|c|c|c|c|c|c|c|}
\hline \multirow{2}{*}{$n=12$} & \multicolumn{3}{|c|}{ Nortes season (Feb'12) } & \multicolumn{3}{|c|}{ Dry season (May'13) } \\
\hline & Median & Min & Max & Median & Min & $\operatorname{Max}$ \\
\hline \multicolumn{7}{|c|}{ Sediment nutrients (\%) } \\
\hline TC & 13.27 & 12.02 & 19.66 & 13.53 & 12.64 & 17.02 \\
\hline $\mathrm{TN}$ & 0.75 & 0.36 & 1.53 & 0.28 & 0.07 & 1.12 \\
\hline $\mathrm{TP}$ & 0.06 & 0.04 & 0.07 & 0.06 & 0.05 & 0.06 \\
\hline $\mathrm{OM}$ & 12.65 & 6.08 & 36.87 & 12.65 & 6.0 & 26.8 \\
\hline $\mathrm{CO}_{3}=$ & 36.17 & 18.41 & 40.97 & 54.17 & 36.4 & 58.97 \\
\hline \multicolumn{7}{|c|}{ Sterols $\mu g g^{-1}$ D.W. } \\
\hline $\mathrm{CO}$ & 0.90 & 0.90 & 96.09 & 6.31 & 0.90 & 42.48 \\
\hline EP & 0.90 & 0.90 & 96.13 & 2.79 & 0.90 & 24.55 \\
\hline $\mathrm{CH}$ & 54.71 & 6.38 & 107.26 & 11.51 & 1.74 & 22.85 \\
\hline $\mathrm{CHL}$ & 69.0 & 0.90 & 104.84 & 8.05 & 0.90 & 35.35 \\
\hline $\mathrm{CA}$ & 43.5 & 0.90 & 78.89 & 0.90 & 0.90 & 11.93 \\
\hline CAL & 0.90 & 0.90 & 96.62 & $\mathrm{ND}$ & $\mathrm{ND}$ & ND \\
\hline ST & 22.7 & 0.90 & 73.09 & 5.03 & 0.90 & 29.50 \\
\hline STL & 0.90 & 0.90 & 76.57 & 3.81 & 1.52 & 27.50 \\
\hline DI & 21.9 & 0.90 & 101.55 & 3.97 & 0.90 & 23.11 \\
\hline SI & 68.6 & 8.11 & 103.28 & 8.81 & 1.75 & 45.11 \\
\hline SIL & 58.8 & 0.90 & 106.49 & $\mathrm{ND}$ & $\mathrm{ND}$ & ND \\
\hline
\end{tabular}

ND: not detected, below detection limit.
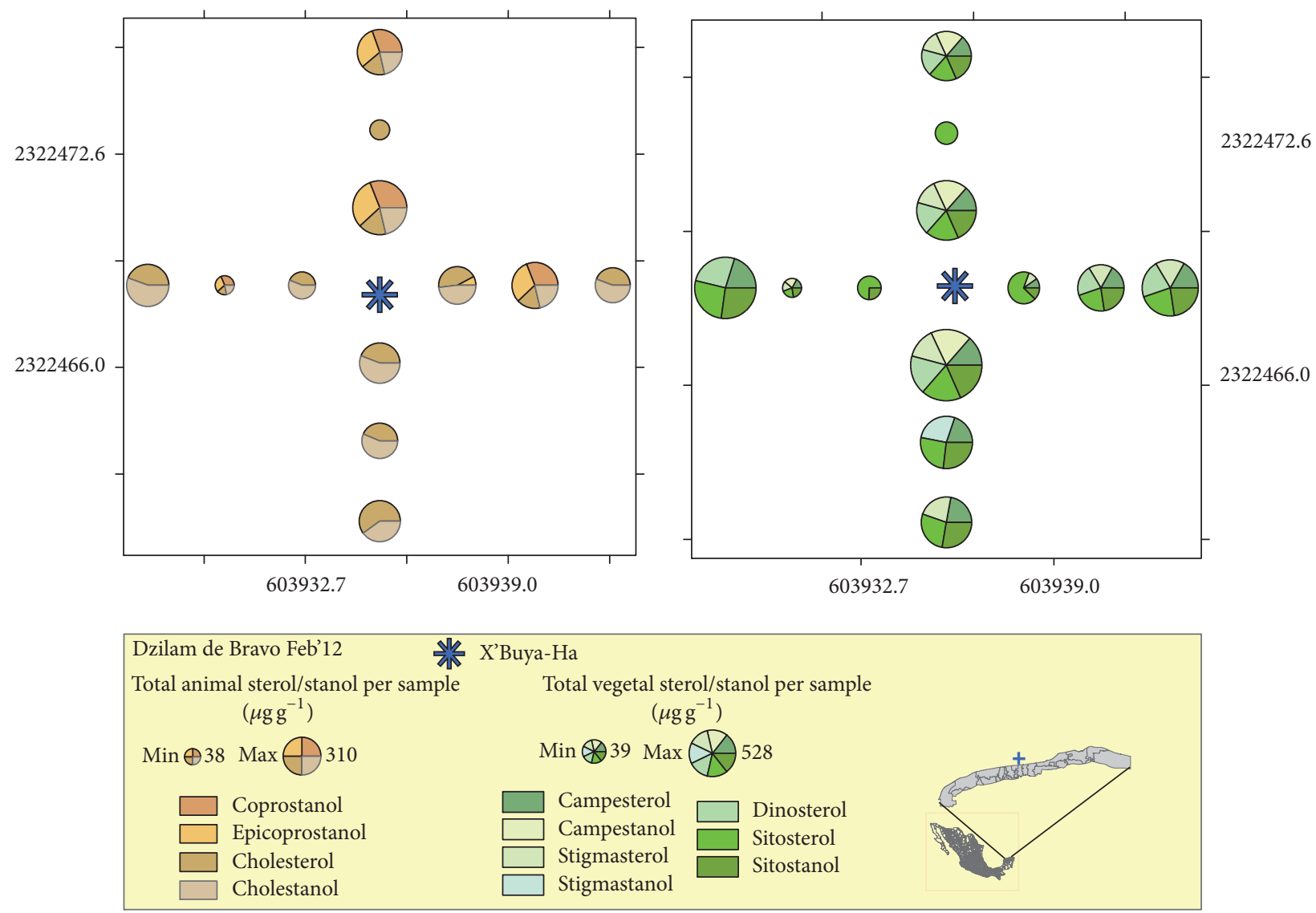

FIGURE 4: Spatial distribution of sterols and stanols in the sediments surrounding the X'Buya-Ha spring for Nortes season (Feb 12). 


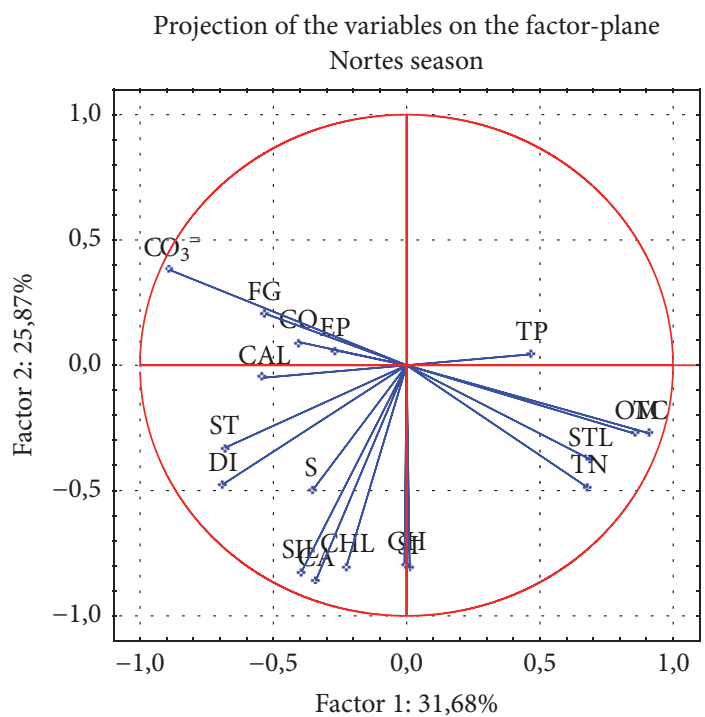

(a)

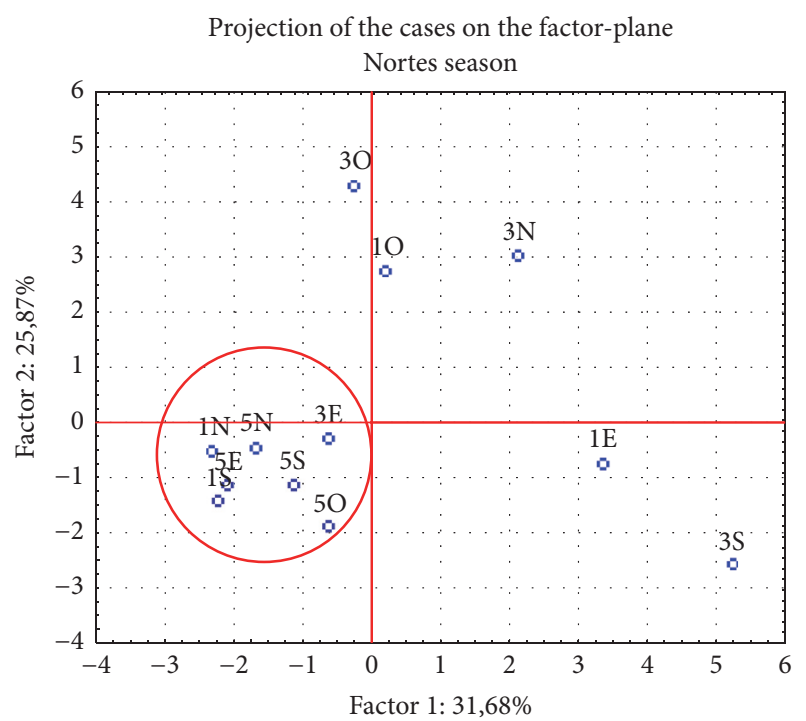

(b)

Figure 5: Principal Component Analysis (PCA) by variable (a) and site (b) based on the presence and concentration of sterols and stanols at each sampling station in Nortes season. The red circle identifies the group that contributes coprostanol (CO) and epicoprostanol (EP).

TABLE 3: Factor analysis for the Nortes season (Feb 2012). Significant values are in italic. CO: coprostanol; EP: epicoprostanol; $\mathrm{CH}$ : cholesterol; CHL: cholestanol; CA: campesterol; STL: stigmastanol; SI: sitosterol; SIL: sitostanol; TC: total carbon; TN: total nitrogen; OM: organic matter; $\mathrm{CO}_{3}{ }^{2}$ : carbonates.

\begin{tabular}{lccc}
\hline Variable & Factor 1 & Factor 2 & Factor 3 \\
\hline $\mathrm{CO}$ & -0.1 & -0.03 & 0.95 \\
$\mathrm{EP}$ & 0.04 & -0.05 & 0.93 \\
$\mathrm{CH}$ & 0.12 & 0.77 & -0.43 \\
$\mathrm{CHL}$ & 0.04 & 0.88 & 0.07 \\
$\mathrm{CA}$ & 0.04 & 0.88 & 0.24 \\
$\mathrm{STL}$ & 0.75 & 0.16 & -0.09 \\
$\mathrm{SI}$ & 0.16 & 0.78 & -0.37 \\
$\mathrm{SIL}$ & -0.06 & 0.93 & 0.17 \\
$\mathrm{TC}$ & 0.98 & -0.06 & -0.05 \\
$\mathrm{TN}$ & 0.89 & 0.16 & 0.05 \\
$\mathrm{OM}$ & 0.91 & -0.06 & -0.16 \\
$\mathrm{CO}$ & $=$ & -0.05 & 0.14 \\
Expl. var. & $\mathbf{4 . 3 1}$ & $\mathbf{3 . 7 6}$ & $\mathbf{2 . 6 5}$ \\
Prp. totl. & $\mathbf{0 . 3 3}$ & $\mathbf{0 . 2 8}$ & $\mathbf{0 . 2 0}$ \\
\hline
\end{tabular}

evidence to support this and further research needs to be done in this regard.

3.3.2. Dry Season (May 2013). As in Nortes season, in dry season, $\mathrm{CH}, \mathrm{SI}$, and ST were also present at all sampling stations (Figure 6).

$\mathrm{CO}$ and EP were found in most of the sampling stations; this could be the result of a decrease of the flow during this season, leading to less transport of suspended material [47]. Therefore, sites with no fecal material content in high flow conditions (near the spring exit) show fecal material presence under low flow conditions. DI was present in fewer sites in dry season than in Nortes season. This might indicate a lower organic matter input from plankton and dinoflagellates $[10,24]$ in this season. Lower plankton abundance during this season has been reported previously [5].

Factor analysis (Table 4) explained $91 \%$ of the variability of the dry season by three factors. Factor 1 characterized by $\mathrm{CO}, \mathrm{EP}, \mathrm{CH}, \mathrm{CHL}, \mathrm{ST}$, STL, and SI suggests not only the presence of allochthonous and marine organic matter but also the possible presence of fecal matter from human and/or animal origin (e.g., CO). It is noteworthy that this factor did not present a direct relation with sediments. It may be a reflection of the complete integration of these compounds in the sedimentary matrix due to a recent introduction or a recent settling down into the sediments.

For the second factor, OM and FG are inversely correlated with carbonates. This observation shows the role of carbonates as diluents of elements and compounds in sediments [33]. Factor 3 consisted of TC and TN concentration, which indicates that there may be allochthonous contributions of $\mathrm{N}$ and $\mathrm{C}$ to the system from the aquifer; however, for these nutrients, autochthonous contributions prevail.

The PCA for dry season (Figures 7(a) and 7(b)) showed a group (circled in red) composed of all the samples collected at a distance of $1 \mathrm{~m}$ and $3 \mathrm{~m}$. This cluster suggests that the flow decreases from the X'Buya-Ha spring, resulting in the settling down of suspended material at the shortest distance from the source. This was previously observed, specifically presence of higher concentrations of coprostanol at relative short distances from sewage outfalls [46]. The second group (circled in blue) is formed by samples collected $5 \mathrm{~m}$ away from the spring. This could be indicating that for dry season the transport of suspended materials in groundwater discharge is limited to $3 \mathrm{~m}$ away from the X'Buya-Ha spring. 

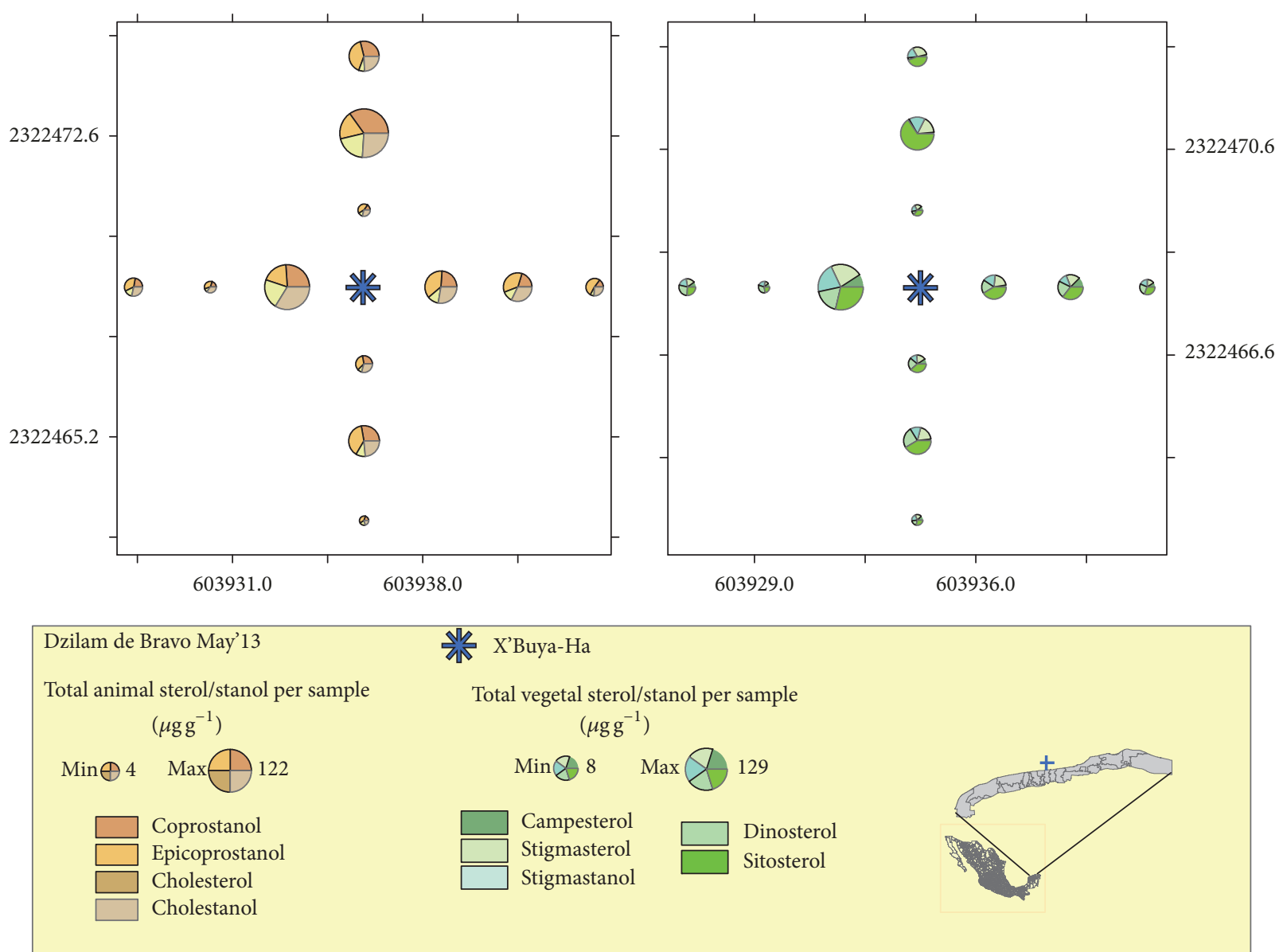

FIGURE 6: Spatial distribution of sterols and stanols surrounding the X’Buya-Ha spring in dry season (May 13).

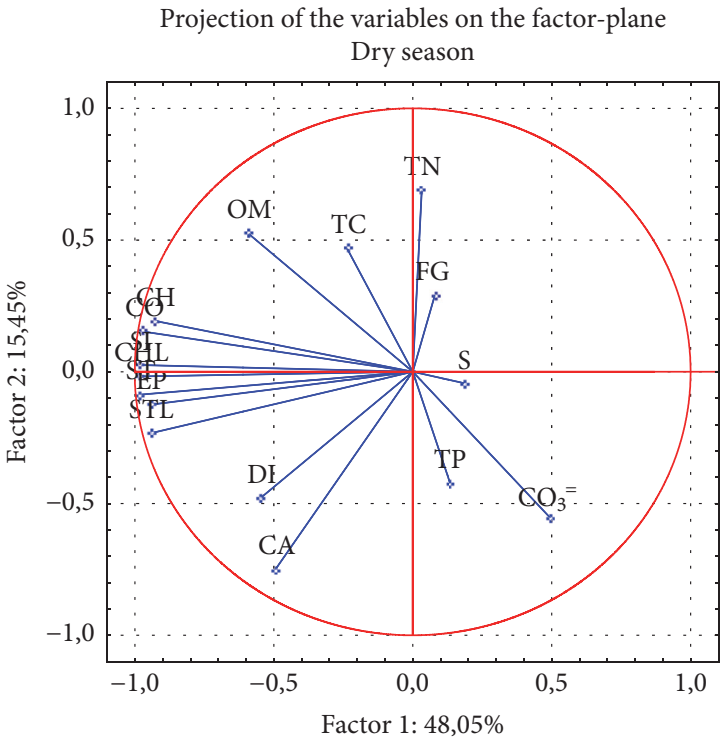

(a)

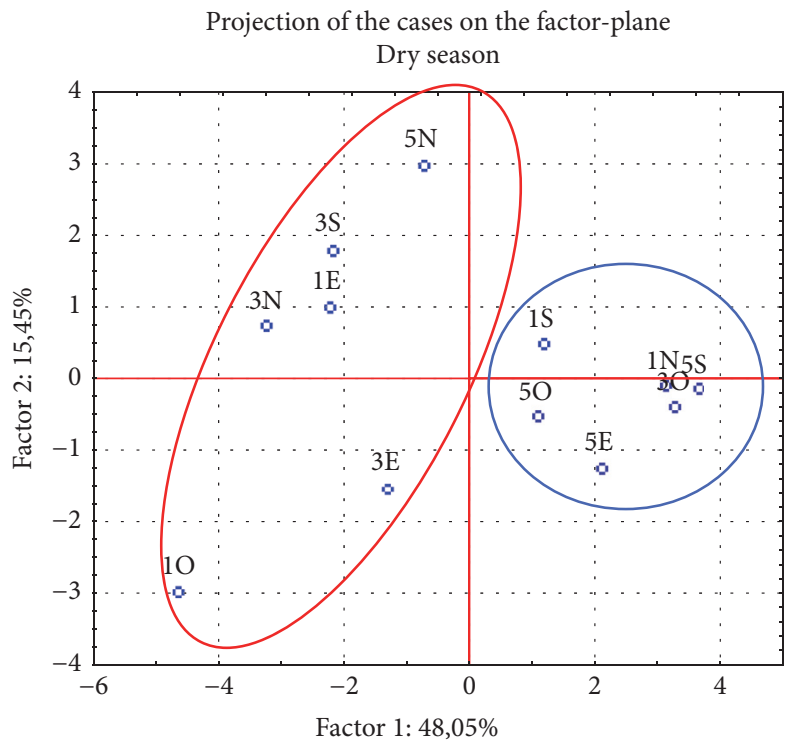

(b)

Figure 7: Principal Component Analysis (PCA) by variable (a) and site (b) based on presence and concentration of sterols at each sampling station in dry season. The red circle identifies the stations with coprostanol and epicoprostanol presence and blue circle includes those stations with little or no influence from the X'Buya-Ha flow. 
TABLE 4: Factor analysis for the dry season (May 2013). Significant values are in italic. $\mathrm{CO}$ : coprostanol; EP: epicoprostanol; $\mathrm{CH}$ : cholesterol; CHL: cholestanol; ST: stigmastanol; STL: stigmastanol; SI: sitosterol; TC: total carbon; TN: total nitrogen; OM: organic matter; $\mathrm{CO}_{3}{ }^{\circ}$ : carbonates; FG: fine grain.

\begin{tabular}{lccc}
\hline Variable & Factor 1 & Factor 2 & Factor 3 \\
\hline $\mathrm{CO}$ & 0.95 & 0.18 & 0.18 \\
$\mathrm{EP}$ & 0.97 & 0.02 & -0.09 \\
$\mathrm{CH}$ & 0.86 & 0.38 & 0.16 \\
$\mathrm{CHL}$ & 0.97 & 0.12 & 0.07 \\
$\mathrm{ST}$ & 0.96 & 0.09 & 0.07 \\
$\mathrm{STL}$ & 0.96 & -0.03 & -0.07 \\
$\mathrm{SI}$ & 0.97 & 0.13 & 0.08 \\
$\mathrm{TC}$ & 0.19 & -0.03 & 0.93 \\
$\mathrm{TN}$ & -0.07 & 0.007 & 0.94 \\
$\mathrm{OM}$ & 0.43 & 0.83 & 0.04 \\
$\mathrm{CO}$ & $=$ & -0.88 & -0.03 \\
FG & -0.3 & 0.75 & -0.09 \\
Expl. var. & -0.23 & $\mathbf{2 . 2 8}$ & $\mathbf{1 . 8 8}$ \\
Prp. totl. & $\mathbf{6 . 7 7}$ & $\mathbf{0 . 1 9}$ & $\mathbf{0 . 1 5}$ \\
\hline
\end{tabular}

Sterols and stanols' fate in both sampling seasons indicates that transport or settling down of suspended material in each site could be a result of flow conditions; therefore distribution will depend on flow velocity and direction that vary between seasons.

Results showed input and distribution of $\mathrm{CO}$ and EP (fecal matter of human origin biomarkers) related with groundwater flux velocity and direction changes in Nortes and dry seasons. This indicates that submerged groundwater discharges are contributing to the coastal areas with allochthonous anthropogenic materials from inland activities $[3,5$, $7,8]$.

\section{Conclusions}

The flow velocity of water emerging from the X'Buya-Ha spring varies significantly between Nortes season and dry season and determines the presence, concentration, and spatial distribution of material in the surrounding area.

Specifically, results showed fecal matter of anthropogenic origin input to the karstic coastal area by the studied submerged groundwater discharge. Also, input of allochthonous organic matter was detected besides the relevant contribution of marine organic matter and nutrients.

In summary, the release of fecal material into the coastal zone by submerged groundwater discharges has a significant temporal and spatial component and indicates that the influence of inland anthropogenic activities increases the risk of fecal contamination in protected coastal zones.

Thus, the nature and extent of the risk created by the pollutants present in groundwater influxes should be investigated further. Legislation should consider before establishing protection perimeters the contribution of submerged groundwater discharges, which can be a significant source of allochthonous anthropogenic fecal material in coastal zones.

\section{Conflicts of Interest}

The authors declare that they have no conflicts of interest.

\section{Acknowledgments}

The authors wish to acknowledge UNAM-PAIP (Project 101914) for funding. They thank Ing. Ismael Oceguera Vargas for his help in lab work, Fernando Mex Esquivel for his help in the sampling campaigns, and Alejandra Martínez Escamilla for project administration.

\section{References}

[1] E. Perry, L. Marin, J. McClain, and G. Velazquez, "Ring of Cenotes (sinkholes), northwest Yucatan, Mexico: its hydrogeologic characteristics and possible association with the Chicxulub impact crater," Geology, vol. 23, no. 1, pp. 17-20, 1995.

[2] L. T. Ghinaglia, J. A. Herrera-Silveira, and F. A. Comín, "Structural variations of phytoplankton in the coastal seas of Yucatan, Mexico," Hydrobiologia, vol. 519, no. 1-3, pp. 85-102, 2004.

[3] N. ArandaCirerol, J. A. Herrera-Silveira, and F. A. Comín, "Nutrient water quality in a tropical coastal zone with groundwater discharge, northwest Yucatán, Mexico," Estuarine, Coastal and Shelf Science, vol. 68, no. 3-4, pp. 445-454, 2006.

[4] A. Valle-Levinson, I. Mariño-Tapia, C. Enriquez, and A. F. Waterhouse, "Tidal variability of salinity and velocity fields related to intense point-source submarine groundwater discharges into the Coastal Ocean," Limnology and Oceanography, vol. 56, no. 4, pp. 1213-1224, 2011.

[5] J. A. Herrera-Silveira and S. M. Morales-Ojeda, "Evaluation of the health status of a coastal ecosystem in southeast Mexico: Assessment of water quality, phytoplankton and submerged aquatic vegetation," Marine Pollution Bulletin, vol. 59, no. 1-3, pp. 72-86, 2009.

[6] L. E. Marín and E. C. Perry, "The hydrology and contamination potential of northwestern Yucatán," Geofísica Internacional, vol. 33, pp. 619-623, 1994.

[7] F. Arcega-Cabrera, N. Velázquez-Tavera, L. Fargher, M. Derrien, and E. Noreña-Barroso, "Fecal sterols, seasonal variability, and probable sources along the ring of cenotes, Yucatan, Mexico," Journal of Contaminant Hydrology, vol. 168, pp. 41-49, 2014.

[8] M. Derrien, F. A. Cabrera, N. L. V. Tavera, C. A. Kantún Manzano, and S. C. Vizcaino, "Sources and distribution of organic matter along the Ring of Cenotes, Yucatan, Mexico: Sterol markers and statistical approaches," Science of the Total Environment, vol. 511, pp. 223-229, 2015.

[9] M. Polemio and P. P. Limoni, "Groundwater pollution and risks for the coastal environment (southeastern Italy)," in Predictions in Ungauged Basins: Promise and Progress, vol. 303, IAHS Publication, 2006, Proceedings of symposium S7 held during the Seventh IAHS Scientific Assembly at Foz do Iguaçu.

[10] J. K. Volkman, "A review of sterol markers for marine and terrigenous organic matter," Organic Geochemistry, vol. 9, no. 2, pp. 83-99, 1986.

[11] M. B. Yunker, R. W. Macdonald, D. J. Veltkamp, and W. J. Cretney, "Terrestrial and marine biomarkers in a seasonally icecovered Arctic estuary-integration of multivariate and biomarker approaches," Marine Chemistry, vol. 49, no. 1, pp. 1-50, 1995.

[12] R. Leeming, A. Ball, N. Ashbolt, and P. Nichols, "Using faecal sterols from humans and animals to distinguish faecal pollution 
in receiving waters," Water Research, vol. 30, no. 12, pp. $2893-$ 2900, 1996.

[13] M. Derrien, E. Jardé, G. Gruau et al., "Origin of fecal contamination in waters from contrasted areas: Stanols as Microbial Source Tracking markers," Water Research, vol. 46, no. 13, pp. 4009-4016, 2012.

[14] C. C. Martins, A. C. Cabral, S. C. T. Barbosa-Cintra, A. L. L. Dauner, and F. M. Souza, "An integrated evaluation of molecular marker indices and linear alkylbenzenes (LABs) to measure sewage input in a subtropical estuary (Babitonga Bay, Brazil)," Environmental Pollution, vol. 188, pp. 71-80, 2014.

[15] R. B. Gagosian and G. E. Nigrelli, "The transport and budget of sterols in the western North Atlantic Ocean," Limnology and Oceanography, vol. 24, no. 5, pp. 838-849, 1979.

[16] M. Derrien, L. Yang, and J. Hur, "Lipid biomarkers and spectroscopic indices for identifying organic matter sources in aquatic environments: A review," Water Research, vol. 112, pp. 58-71, 2017.

[17] C. Lee and S. G. Wakeham, "Organic matter in sea-water: biogeochemical processes," in Chemical oceanography, J. P. Riley, Ed., pp. 1-51, Academic Press, New York, NY, USA, 1988.

[18] E. D. Hudson, C. C. Parrish, and R. J. Helleur, "Biogeochemistry of sterols in plankton, settling particles and recent sediments in a cold ocean ecosystem (Trinity Bay, Newfoundland)," Marine Chemistry, vol. 76, no. 4, pp. 253-270, 2001.

[19] H. F. Henry and W. A. Suk, "Public health and karst groundwater contamination: from multidisciplinary research to exposure prevention," in Karst Groundwater Contamination and Public Health, W. White, J. Herman, E. Herman, and M. Rutigliano, Eds., Advances in Karst Science, pp. 7-14, Springer International Publishing, Chambridge, UK, 2018.

[20] J. Laurcillard and A. Saliot, "Biomarkers in organic matter produced in estuaries: a case study of the Krka estuary (Adriatic Sea) using the sterol marker series," Marine Chemistry, vol. 43, no. 1-4, pp. 247-261, 1993.

[21] W.-Y. Huang and W. G. Meinschein, "Sterols as ecological indicators," Geochimica et Cosmochimica Acta, vol. 43, no. 5, pp. 739-745, 1979.

[22] R. G. Kerr and B. J. Baker, "Marine sterols," Natural Product Reports, vol. 8, no. 5, pp. 465-497, 1991.

[23] I. Lahdelma and A. Oikari, "Stratigraphy of wood-derived sterols in sediments historically contaminatedby pulp and paper mill effluents," Journal of Paleolimnology, vol. 35, no. 2, pp. 323334, 2006.

[24] I. Bouloubassi, E. Lipiatou, A. Saliot, I. Tolosa, J. M. Bayona, and J. Albaiges, "Carbon sources and cycle in the western Mediterranean - The use of molecular markers to determine the origin of organic matter," Deep-Sea Research Part II: Topical Studies in Oceanography, vol. 44, no. 3-4, pp. 781-799, 1997.

[25] J. O. Grimalt, P. Fernandez, J. M. Bayona, and J. Albaiges, "Assessment of fecal sterols and ketones as indicators of urban sewage inputs to coastal waters," Environmental Science \& Technology, vol. 24, no. 3, pp. 357-363, 1990.

[26] M. Kantún, Nutrient contribution by submerged groundwater discharges to the coastal zone of Dzilam de Bravo [Master, thesis], CINVESTAV, Yucatan, Mexico, 2011.

[27] C. Enriquez, I. J. Mariño-Tapia, and J. A. Herrera-Silveira, "Dispersion in the Yucatan coastal zone: Implications for red tide events," Continental Shelf Research, vol. 30, no. 2, pp. 127-137, 2010.
[28] B. Steinich and L. E. Marin, "Hydrogeological investigations in Northwestern Yucatan, Mexico, using resistivity surveys," Groundwater, vol. 34, no. 4, pp. 640-646, 1996.

[29] R. González-Herrera, I. Sánchez-y-Pinto, and J. GamboaVargas, "Groundwater-flow modeling in the Yucatan karstic aquifer, Mexico," Hydrogeology Journal, vol. 10, no. 5, pp. 539$552,2002$.

[30] C. Martínez-Navarrete and A. García-García, "La delimitación de perímetros de protección de captaciones de agua subterránea para abastecimiento de poblaciones en acuíferos costeros. Aspectos legales y metodológicos," in Tecnología de la intrusión de agua de mar en acuíferos costeros: países mediterráneos, IGME, Madrid, Spain, 2003.

[31] K. I. Aspila, H. Agemian, and A. S. Y. Chau, "A semi-automated method for the determination of inorganic, organic and total phosphate in sediments," Analyst, vol. 101, no. 1200, pp. 187-197, 1976.

[32] W. E. Dean Jr., "Determination of carbonate and organic matter in calcareous sediments and sedimentary rocks by loss on ignition: Comparison with other methods," Journal of Sedimentary Petrology, vol. 44, pp. 242-248, 1974.

[33] D. H. Loring and R. T. T. Rantala, "Manual for the geochemical analyses of marine sediments and suspended particulate matter," Earth-Science Reviews, vol. 32, no. 4, pp. 235-283, 1992.

[34] R. Paulsen, C. Smith, and D. O’Rourke, Peconic estuary: a preliminary analysis of the relationship between submarine groundwater discharge (sdg) and submerged aquatic vegetation in the peconic estuary, U.S. Environmental Protection Agency, Washington, D.C., Wash, USA, 2004.

[35] D. W. Urish and T. E. McKenna, "Tidal effects on ground water discharge through a sandy marine beach," Groundwater, vol. 42, no. 7, pp. 971-982, 2004.

[36] J. A. Herrera-Silveira, "Phytoplankton productivity and submerged macrophyte biomass variation in a tropical coastal lagoon with groundwater discharge," Vie et Milieu, vol. 44, no. 3-4, pp. 257-266, 1994.

[37] M. S. Fonseca and S. S. Bell, "Influence of physical setting on seagrass landscapes near Beaufort, North Carolina, USA," Marine Ecology Progress Series, vol. 171, pp. 109-121, 1998.

[38] F. J. Urrutia, A. Camargo-Z, and L. Perez C, "he Chicxulub multi-ring impact crater, Yucatan carbonate platform," Geofísica Internacional, vol. 50, no. 1, pp. 99-127, 2011.

[39] J. K. Volkman, "Sterols and other triterpenoids: Source specificity and evolution of biosynthetic pathways," Organic Geochemistry, vol. 36, no. 2, pp. 139-159, 2005.

[40] H. R. Harvey, "Fatty acids and sterols as source markers of organic matter in sediments of the North Carolina continental slope," Deep-Sea Research Part II: Topical Studies in Oceanography, vol. 41, no. 4-6, pp. 783-796, 1994.

[41] K.-H. Chan, M. H. W. Lam, K.-F. Poon, H.-Y. Yeung, and T. K. T. Chiu, "Application of sedimentary fecal stanols and sterols in tracing sewage pollution in coastal waters," Water Research, vol. 32, no. 1, pp. 225-235, 1998.

[42] R. S. Carreira, A. L. R. L. Wagener, and J. W. Readman, "Sterols as markers of sewage contamination in a tropical urban estuary (Guanabara Bay, Brazil): space-time variations," Estuarine, Coastal and Shelf Science, vol. 60, no. 4, pp. 587-598, 2004.

[43] J. Wu, P. Rees, S. Storrer, K. Alderisio, and S. Dorner, "Fate and transport modeling of potential pathogens: The contribution from sediments," JAWRA Journal of the American Water Resources Association, vol. 45, no. 1, pp. 35-44, 2009. 
[44] D. T. Bennie, C. A. Sullivan, H.-B. Lee, T. E. Peart, and R. J. Maguire, "Occurrence of alkylphenols and alkylphenol monoand diethoxylates in natural waters of the Laurentian Great Lakes basin and the upper St. Lawrence River," Science of the Total Environment, vol. 193, no. 3, pp. 263-275, 1997.

[45] A. Cuevas-Jiménez and J. Euán-Ávila, "Morphodynamics of carbonate beaches in the Yucatán Peninsula," Ciencias Marinas, vol. 35, no. 3, pp. 307-320, 2009.

[46] R. C. Brown and T. L. Wade, "Sedimentary coprostanol and hydrocarbon distribution adjacent to a sewage outfall," Water Research, vol. 18, no. 5, pp. 621-632, 1984.

[47] C. Pratt, J. Warnken, R. Leeming, M. J. Arthur, and D. I. Grice, "Degradation and responses of coprostanol and selected sterol biomarkers in sediments to a simulated major sewage pollution event: A microcosm experiment under sub-tropical estuarine conditions," Organic Geochemistry, vol. 39, no. 3, pp. 353-369, 2008. 

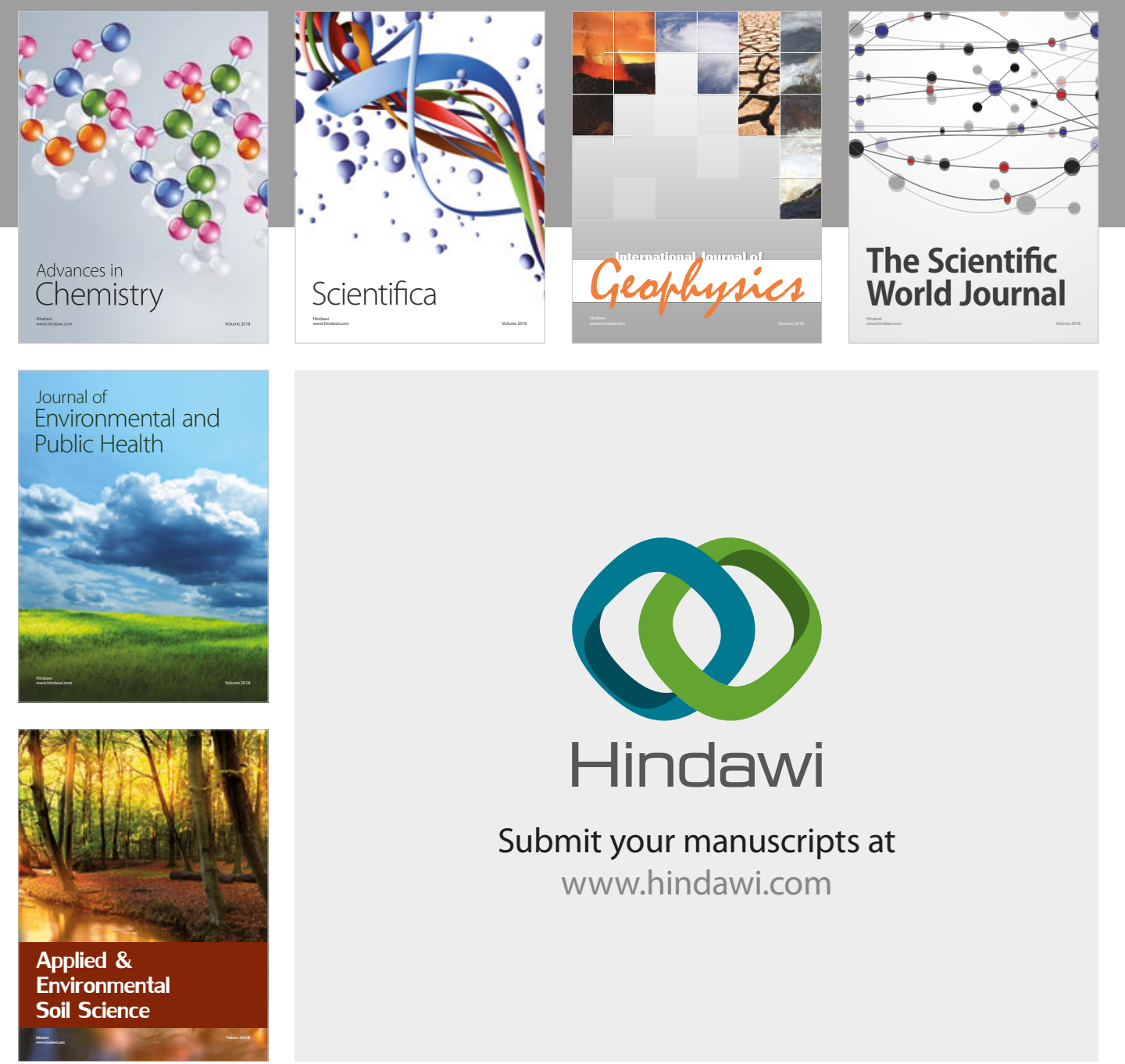

The Scientific

\section{World Journal}
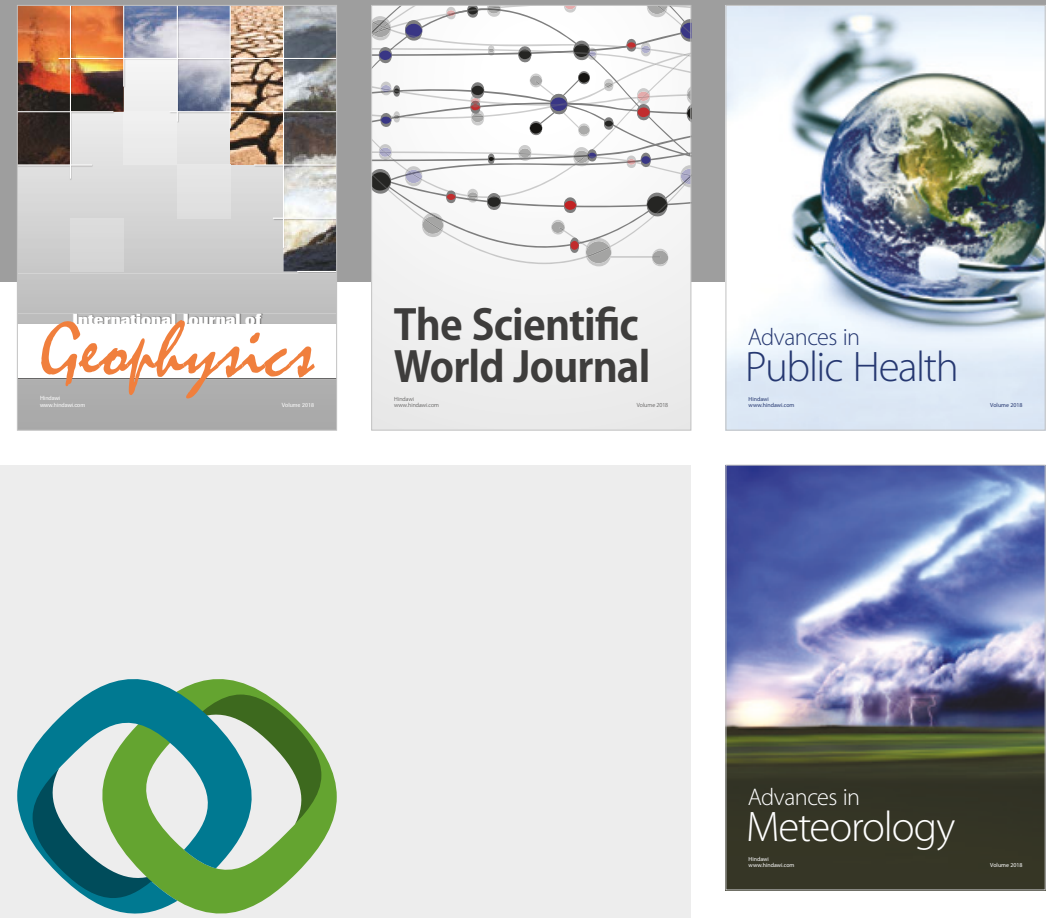

Advan

Public Health

\section{Hindawi}

Submit your manuscripts at

www.hindawi.com
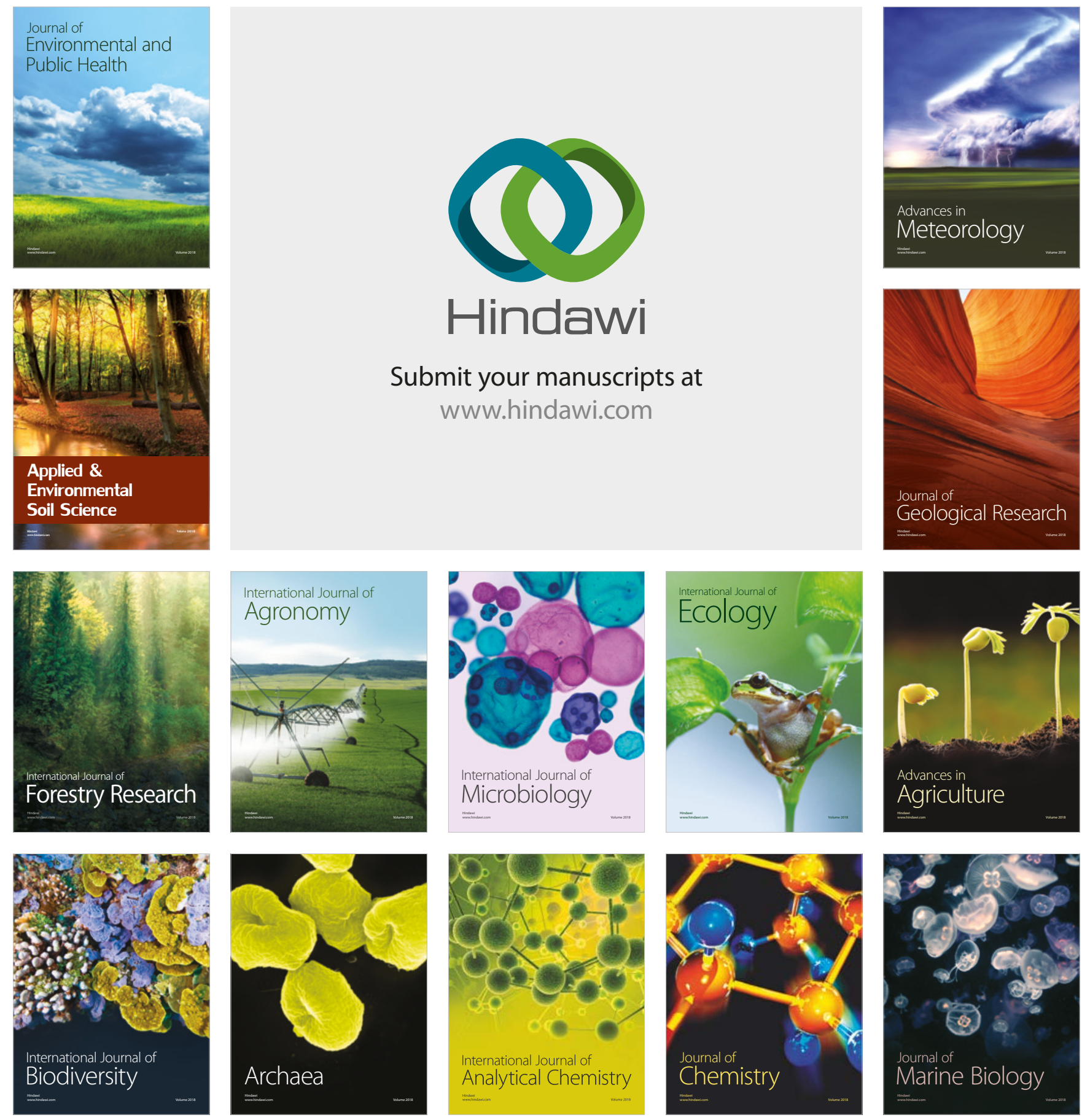